\title{
Effect of different tumbling marination methods and time on the quality characteristics of prepared pork chops
}

\author{
Tian $\mathrm{GAO}^{1}$, Jiaolong $\mathrm{LI}^{1}$, Lin ZHANG ${ }^{1}$, Yun JIANG ${ }^{2}$, Yang $\mathrm{LIU}^{1}$, Xin $\mathrm{ZHANG}^{1}$, Feng $\mathrm{GAO}^{1 *}$, Guanghong ZHOU
}

\begin{abstract}
The combined effects of tumbling marination methods (Vacuum continuous tumbling marination, CT; Vacuum intermittent tumbling marination, IT) and effective tumbling time $(4,6,8$ and $10 \mathrm{~h})$ on quality characteristics of prepared boneless pork chops were investigated. The results showed that regardless of tumbling time, CT method significantly increased the $\mathrm{pH}$, product yield, cohesiveness, resilience, sensory tenderness and overall flavor $(p<0.05)$ compared with IT method, and CT method also significantly decreased the pressing loss, cooking loss, shear force value (SFV), hardness and chewiness $(p<0.05)$ compared with IT method. With the effective tumbling time increasing from $4 \mathrm{~h}$ to $10 \mathrm{~h}$, the product yield and sensory attributes of prepared pork chops increased at first and then decreased, whereas the pressing loss, cooking loss, SFV, hardness and chewiness decreased at first and then increased. Additionally, an interaction between CT method and effective tumbling time was also observed. These results suggested that CT method of $8 \mathrm{~h}$ obtained the best quality characteristics of prepared pork chops, which should be adopted.
\end{abstract}

Keywords: continuous; intermittent; tumbling time; quality characteristic; prepared pork chop.

Practical Application: The continuous tumbling of $8 \mathrm{~h}$ should be adopted for quality control and meat processing industry.

\section{Introduction}

Nowadays, marinating pork chops have become a fairly integral part of the swine industry due to the increasing demand for further processed, ready-to-eat and higher nutritional value of foods. Moreover, the demand for the prepared pork chop has been continuously growing in most of eastern countries, especially in China. The Chinese consumption of pork meat accounts for nearly half of that of the whole world (United States Department of Agriculture, 2013).

In the meat processing industry, marination technologies have successfully applied to meet consumer demands and improve the nutritional quality of meat or meat products (Saha et al., 2009). Generally, the marination technology is defined as immersing meat in a liquid marinade and allowing it to penetrate into the meat through diffusion over time (Yusop et al., 2010). Commercial marinade usually involves a more complex solution of water, salt $(\mathrm{NaCl})$, polyphosphates, flavorings and other ingredients.

The marination process is often complemented with tumbling of the meat. As the most severe kind of physico-mechanical treatment process, tumbling involves meat rotating, falling, and contacting with metal walls and paddles in a drum (Kim et al., 2012). Tumbling is also favorable from an eating point of view, since it results in a more tender and juicy meat (Hullberg \& Lundström, 2004). The two major methods of tumbling treatment are continuous and intermittent tumbling. There are different interval times in the process of intermittent tumbling treatment. So, intermittent tumbling could obtain a balance between optimal tumbling time and marinade migration time (Hayes et al., 2007), whereas the mechanical energy of continuous tumbling might avoid intrinsically elastic shrink of tumbled meat samples occurring in the "rest period" of intermittent tumbling process. Although several studies found some advantages of intermittent tumbling treatment (Ockerman \& Organisciak, 1978; Plimpton et al., 1991). Gillett et al. (1982) still suggested that continuous tumbling is more effective than intermittent tumbling.

However, to the authors' knowledge, there is little information available on the effect of tumbling marination regimes, e.g., continuous or intermittent tumbling, tumbling time, drum speed and degree of loading of drum on quality characteristics of the present prepared boneless pork chops. And consequently, the purpose of this study was to investigate the effect of two most critical factors of tumbling marination methods (continuous vs. intermittent tumbling) and actual tumbling time (4, 6, 8 and $10 \mathrm{~h}$ ) on the quality characteristics of prepared pork chops, for obtaining the most optimal technological parameters for widespread industrial production.

\section{Materials and methods}

\subsection{Meat samples and experimental design}

The fresh whole pork loin (Longissimus dorsi) obtained randomly from a local slaughterhouse at $48 \mathrm{~h}$ post-mortem was used in the present study. The average weight of slaughtered 
DLY cross bred barrow pigs (Duroc boar crossed with Danish Yorkshire/Danish Landrace sow) was approximately $95 \mathrm{~kg}$. The pork loins were chosen as it could be considered as a relatively homogenous muscle with the normal $\mathrm{pH}$ value $5.57 \pm 0.03$. After the removal of all external fat, fascia and separable connective tissue, the pork loins were packed in low density polyethylene bags temporarily and stored at $2{ }^{\circ} \mathrm{C}$ for subsequent experiments.

Necessary preliminary trials were conducted to establish the appropriate marinade formulation for this kind of prepared pork chops. The selected marinade solution consisted of sodium chloride ( $\mathrm{NaCl}) 42.86 \mathrm{~g}$, sodium pyrophosphate (TSPP) $4.00 \mathrm{~g}$, sodium tripolyphosphate (STPP) $2.29 \mathrm{~g}$, sodium hexametphosphate (SHMP) $2.29 \mathrm{~g}$, white pepper powder $8.57 \mathrm{~g}$ and $1000 \mathrm{~g}$ water. $\mathrm{NaCl}$ and polyphosphates were analytical grade and were purchased from Xuzhou Tianjia Chemical Plant Co. Limited (Xuzhou, China). The white pepper powder was purchased from Kunshan Spices Co. Limited (Kunshan, China). When testing, the pork loins were cut into chop samples of approximately the same weight and size $(80 \mathrm{~g}$ with $10 \mathrm{~cm} \times 5 \mathrm{~cm} \times 2 \mathrm{~cm})$. The length of pork chops was $10 \mathrm{~cm}$ and parallel to the muscle fiber direction of pork loins. The ratio of meat weight to marinade weight was 100:35 for all treatments.

The present study applied a $2 \times 4$ factorial experimental design with two tumbling marination methods (Vacuum continuous tumbling marination, CT; Vacuum intermittent tumbling marination, IT) and four actually effective tumbling time $(4,6,8$ and $10 \mathrm{~h})$. The intermittent schedule was $20 \mathrm{~min}$ on and $10 \mathrm{~min}$ off for the total treatment time of 6, 9, 12 and $15 \mathrm{~h}$ with the actually effective tumbling time equal to $4,6,8$ and $10 \mathrm{~h}$, respectively. The cut pork chops and marinade were placed in a vacuum tumbler (ESK-125, Kakona GmbH Company, Kempten, Germany) with tumbling conditions of 11 revolutions per minute, vacuum at $90 \%$, temperature at $2^{\circ} \mathrm{C}$ and the degree of loading of drum at $55^{\circ} \mathrm{C}$ for all treatments. Eight treatments were named as CT- $4 \mathrm{~h}$, CT- 6 h, CT- 8 h, CT- $10 \mathrm{~h}$, IT- $4 \mathrm{~h}$, IT- $6 \mathrm{~h}$, IT- $8 \mathrm{~h}$ and IT- $10 \mathrm{~h}$, respectively. All eight treatments were replicated three times resulting in total 96 samples. After the marination experiments, all samples were dabbed with tissue paper to absorb surface water for the further analysis.

\section{$2.2 \mathrm{pH}$ measurement}

pH was measured with an insertion electrode (HI-9125, HANNA instruments, Cluj-Napoca, Romania) after treatments according to the method of Straadt et al. (2007). The pH meter was standardized by buffer solutions ( $\mathrm{pH} 7.00$ and 4.01) before testing and compensated for temperature at $20^{\circ} \mathrm{C}$ together with the chop samples. Each sample was measured 3 times at various points and the average value was used.

\subsection{Pressing loss}

The pressing loss was measured after marination experiment by a modification of the procedure of Farouk \& Wieliczko (2003). Briefly, approximately $5 \mathrm{~g}$ sample was cut from each pork chop by a $25.2 \mathrm{~mm}$ coring tool. Then sample was wrapped with 16 layers of tissue papers and pressed with a $35 \mathrm{~kg}$ weight for 5 min using a compression machine (YYW-2, Nanjing Soil
Instrument, Nanjing, China). The pressing loss (\%) was calculated as a percentage of weight loss before and after compression.

\subsection{Cooking loss}

Cooking loss was measured by the method of Sheard \& Tali (2004) with some modifications. The cooking loss (\%) was determined as the difference between the fresh and cooked weight divided by the fresh weight.

\subsection{Product yield}

The following equation (Equation 1) was used to calculate the product yield as described by Cheng et al. (2011).

Product yield $(\%)=\mathrm{W}_{2} / \mathrm{W}_{1} * 100$

where $\mathrm{W}_{1}$ was the weight of fresh pork chops (before marination experiment), and $\mathrm{W}_{2}$ was the weight of marinated and cooked pork chops.

\subsection{Warner-Bratzler shear force value (SFV)}

The SFV was determined by the method of Peña et al. (2014) using a texture analyzer (TA-XT2i, Stable Micro Systems Ltd., Surry, England) equipped with a Warner-Bratzler shear device. Maximum peak force recorded during the test was reported as SFV and the result was expressed in Newton's (N).

\subsection{Texture profile analyses (TPA)}

TPA was performed using a texture analyzer (TA-XT2i, Stable Micro Systems Ltd., Surry, England) as described by Bourne (1978) with some modifications. Chop samples after the cooking process were allowed to equilibrate to room temperature of $20^{\circ} \mathrm{C}$ and cut into $20 \mathrm{~mm}$ height across to the myofiber direction by a cylinder sampler of $25.2 \mathrm{~mm}$ in diameter. The cut samples were compressed applying a double compression test (TPA) across the myofiber direction to $50 \%$ of their original height at $1.0 \mathrm{~mm} / \mathrm{s}$ using a cylindrical-shaped piston $50 \mathrm{~mm}$ in diameter $(\mathrm{P} / 50)$. The conditions of texture analysis were as follows: pre-test speed $2.0 \mathrm{~mm} / \mathrm{s}$, post-test speed $5.0 \mathrm{~mm} / \mathrm{s}$, return distance $30 \mathrm{~mm}$, trigger force $10 \mathrm{~g}$.

\subsection{Sensory evaluation}

Pork chops were assessed for a number of sensory characteristics by an experienced eight member trained panel in sensory evaluation by the method of Ruiz de Huidobro et al. (2003) with some modifications. Firstly, necessary preliminary training sessions were conducted to familiarize the panelists with the characteristics to be evaluated, i.e. tenderness, color, juiciness, overall flavor and overall acceptability. Secondly, for the testing sessions, the characteristics were evaluated using a 1-6 point category scale $(6=$ excellent color uniformity/ extremely good flavor/extremely acceptable; $1=$ very poor color/very poor flavor/not acceptable) or 1-8 point category scale $(8=$ extremely tender/juicy; $1=$ extremely tough/dry). Chop samples were prepared for presentation by cutting $2 \mathrm{~mm}$ thick slice (parallel to the muscle fiber direction) immediately 
after the cooking process. Every five slice samples in the tray were labeled with three digit random numbers and served in random order to each panelist in individual booths at room temperature of $20^{\circ} \mathrm{C}$. Each treatment was presented to each panelist twice for each of three replicates. Water was provided to rinse the mouth between the samples.

\subsection{Statistical analysis}

All data were analyzed by analysis of variance using the General Linear Model (GLM) procedure of the SAS statistical package (Statistics Analysis System 8.1, SAS Inc., Chicago, USA) for significant differences among treatment means based on tumbling marination methods, tumbling time and their interactions. If significant differences $(p<0.05)$ were found in factors, the Duncan's new multiple range test was used to rank the means.

\section{Results}

\section{1 pH value}

Table 1 showed that CT method significantly increased $\mathrm{pH}$ value than IT method regardless of tumbling time $(p<0.05)$. The $\mathrm{pH}$ value increased with the effective tumbling time increasing from $4 \mathrm{~h}$ to $10 \mathrm{~h}(p<0.05)$, and the highest value was obtained at $10 \mathrm{~h}$. Additionally, there was interactive effect on the $\mathrm{pH}$ value between tumbling methods and effective tumbling time $(p<0.05)$ with the highest value observed in CT method of $10 \mathrm{~h}$.

\subsection{Product yield}

Table 1 showed that regardless of tumbling time, CT method significantly increased the product yield (\%) of prepared pork chops compared with IT method $(p<0.05)$. Whereas the product yield increased at first and then decreased with the effective tumbling time increasing from $4 \mathrm{~h}$ to $10 \mathrm{~h}$. In addition, the product yield was significantly affected by the interaction of tumbling methods and effective tumbling time $(p<0.05)$ with the highest result observed in CT method of $8 \mathrm{~h}$.

\subsection{Pressing loss, cooking loss and shear force value}

Table 1 showed that regardless of tumbling time, CT method significantly decreased the pressing loss (\%), cooking loss (\%) and SFV $(\mathrm{N})$ of pork chops compared with IT method $(p<0.05)$. With the effective tumbling time increasing from $4 \mathrm{~h}$ to $10 \mathrm{~h}$, the pressing loss, cooking loss and SFV decreased at first and then increased, and the cooking loss of $8 \mathrm{~h}$ was significantly lower than the other treatments $(p<0.05)$. In addition, the cooking loss and SFV were significantly affected by the interaction of tumbling methods and tumbling time $(p<0.05)$.

\subsection{Texture profile analyses (TPA)}

Table 2 shows regardless of tumbling time, CT method significantly decreased hardness, chewiness and significantly increased cohesiveness and resilience of prepared pork chops than IT method $(p<0.05)$. With the increasing of effective tumbling time from $4 \mathrm{~h}$ to $10 \mathrm{~h}$, the hardness and chewiness decreased at first and then increased, and the lowest values or

Table 1. Effect of different tumbling marination methods and time on the $\mathrm{pH}$ value, product yield, pressing loss, cooking loss and shear force value of prepared pork chop.

\begin{tabular}{|c|c|c|c|c|c|}
\hline Items & $\mathrm{pH}$ value & Product yield (\%) & Pressing loss (\%) & Cooking loss (\%) & Shear force value $(\mathrm{N})$ \\
\hline CT-4h & $5.59 \pm 0.02^{\mathrm{d}}$ & $77.20 \pm 1.28^{\mathrm{d}}$ & $40.10 \pm 0.92$ & $24.22 \pm 0.51^{b c}$ & $17.33 \pm 0.63^{\mathrm{b}}$ \\
\hline CT-6h & $5.62 \pm 0.01^{\mathrm{cd}}$ & $78.23 \pm 0.87^{\mathrm{cd}}$ & $38.21 \pm 0.75$ & $22.99 \pm 0.75^{\mathrm{cd}}$ & $14.24 \pm 0.58^{\mathrm{d}}$ \\
\hline CT-8h & $5.82 \pm 0.01^{\mathrm{b}}$ & $82.02 \pm 1.54^{\mathrm{a}}$ & $37.64 \pm 0.58$ & $14.31 \pm 0.72^{\mathrm{f}}$ & $12.38 \pm 0.96^{\mathrm{e}}$ \\
\hline CT-10h & $5.88 \pm 0.05^{\mathrm{a}}$ & $80.62 \pm 1.32^{\mathrm{ab}}$ & $41.02 \pm 0.51$ & $19.82 \pm 1.35^{\mathrm{e}}$ & $17.19 \pm 0.75^{\mathrm{b}}$ \\
\hline IT-4h & $5.58 \pm 0.05^{\mathrm{d}}$ & $77.44 \pm 1.38^{\mathrm{d}}$ & $40.81 \pm 0.64$ & $24.89 \pm 1.46^{\mathrm{b}}$ & $17.80 \pm 1.07^{\mathrm{b}}$ \\
\hline IT-6h & $5.60 \pm 0.01^{\mathrm{d}}$ & $79.21 \pm 0.67^{b c}$ & $39.71 \pm 0.32$ & $23.97 \pm 0.42^{b c}$ & $15.58 \pm 0.55^{c}$ \\
\hline IT-8h & $5.68 \pm 0.01^{c}$ & $79.62 \pm 1.27^{\mathrm{bc}}$ & $38.68 \pm 0.54$ & $22.56 \pm 1.31^{\mathrm{d}}$ & $14.80 \pm 0.57^{\mathrm{cd}}$ \\
\hline IT-10h & $5.76 \pm 0.08^{b}$ & $67.43 \pm 1.83^{\mathrm{e}}$ & $42.77 \pm 0.47$ & $28.90 \pm 0.66^{\mathrm{a}}$ & $20.27 \pm 0.54^{\mathrm{a}}$ \\
\hline \multicolumn{6}{|l|}{ Methods } \\
\hline $\mathrm{CT}$ & $5.73 \pm 0.13^{\mathrm{a}}$ & $79.52 \pm 2.12^{\mathrm{a}}$ & $39.24 \pm 1.55^{\mathrm{b}}$ & $20.34 \pm 4.04^{\mathrm{b}}$ & $15.29 \pm 2.26^{\mathrm{b}}$ \\
\hline IT & $5.66 \pm 0.08^{b}$ & $75.93 \pm 5.26^{b}$ & $40.49 \pm 1.64^{\mathrm{a}}$ & $25.08 \pm 2.57^{\mathrm{a}}$ & $17.11 \pm 2.31^{\mathrm{a}}$ \\
\hline \multicolumn{6}{|l|}{ Time } \\
\hline $4 \mathrm{~h}$ & $5.59 \pm 0.01^{b}$ & $77.32 \pm 0.33^{\mathrm{ab}}$ & $40.45 \pm 0.81^{\mathrm{b}}$ & $24.56 \pm 1.05^{\mathrm{a}}$ & $17.57 \pm 0.83^{\mathrm{a}}$ \\
\hline $6 \mathrm{~h}$ & $5.61 \pm 0.01^{b}$ & $78.72 \pm 0.88^{\mathrm{ab}}$ & $38.95 \pm 0.97^{c}$ & $23.48 \pm 0.76^{\mathrm{a}}$ & $14.91 \pm 0.89^{b}$ \\
\hline $8 \mathrm{~h}$ & $5.75 \pm 0.07^{\mathrm{a}}$ & $80.82 \pm 1.37^{\mathrm{a}}$ & $38.16 \pm 0.76^{c}$ & $18.44 \pm 4.54^{\mathrm{b}}$ & $13.59 \pm 1.50^{\mathrm{b}}$ \\
\hline $10 \mathrm{~h}$ & $5.82 \pm 0.09^{a}$ & $74.03 \pm 4.33^{\mathrm{b}}$ & $41.89 \pm 1.06^{\mathrm{a}}$ & $24.36 \pm 4.99^{\mathrm{a}}$ & $18.73 \pm 1.78^{\mathrm{a}}$ \\
\hline \multicolumn{6}{|c|}{ Two-way ANOVA } \\
\hline Methods & 0.001 & $<.0001$ & 0.001 & $<.0001$ & $<.0001$ \\
\hline Time & $<.0001$ & 0.037 & $<.0001$ & 0.018 & $<.0001$ \\
\hline Interaction & 0.014 & $<.0001$ & 0.482 & $<.0001$ & 0.034 \\
\hline
\end{tabular}

${ }^{a-e}$ Means with different letters in the same column (within each main effect or interaction) are significantly different $(p<0.05)$. Values are reported as means \pm S.D. (standard deviation) of three replicates. $\mathrm{CT}=$ vacuum continuous tumbling marination; $\mathrm{IT}=$ vacuum intermittent tumbling marination. 
best results were both achieved at $8 \mathrm{~h}$. Whereas the springiness, cohesiveness and resilience increased at first and then decreased, and the highest results were both achieved at $6 \mathrm{~h}$. In addition, the hardness, chewiness and resilience were significantly affected by the interaction of tumbling methods and tumbling time $(p<0.05)$.

\subsection{Sensory evaluation}

Table 3 showed that regardless of tumbling time, CT method significantly increased the tenderness and overall flavor of pork chops compared with IT method $(p<0.05)$. Despite tumbling method, the sensory attributes of prepared pork chops first increased and then decreased with the increasing of effective

Table 2. Effect of different tumbling marination methods and time on the textural characteristics of prepared pork chop.

\begin{tabular}{|c|c|c|c|c|c|}
\hline Items & Hardness (g) & Springiness $(\mathrm{cm})$ & Cohesiveness (unitless) & Chewiness $\left(\mathrm{g}^{*} \mathrm{~cm}\right)$ & Resilience (unitless) \\
\hline CT-4h & $11884 \pm 89.5^{\mathrm{b}}$ & $0.63 \pm 0.02$ & $0.63 \pm 0.01$ & $4721 \pm 132^{\mathrm{bc}}$ & $0.26 \pm 0.01^{\mathrm{b}}$ \\
\hline CT-6h & $11149 \pm 224^{\mathrm{cd}}$ & $0.65 \pm 0.01$ & $0.69 \pm 0.01$ & $4834 \pm 149^{b}$ & $0.28 \pm 0.01^{\mathrm{a}}$ \\
\hline CT-8h & $8602 \pm 46.8^{f}$ & $0.65 \pm 0.03$ & $0.65 \pm 0.03$ & $3506 \pm 86.1^{\mathrm{e}}$ & $0.28 \pm 0.02^{\mathrm{a}}$ \\
\hline CT- $10 \mathrm{~h}$ & $10198 \pm 269^{e}$ & $0.62 \pm 0.01$ & $0.65 \pm 0.01$ & $4145 \pm 278^{\mathrm{d}}$ & $0.28 \pm 0.01^{\mathrm{a}}$ \\
\hline IT- $4 \mathrm{~h}$ & $11865 \pm 68.9^{\mathrm{b}}$ & $0.62 \pm 0.01$ & $0.61 \pm 0.02$ & $4504 \pm 178^{c}$ & $0.27 \pm 0.01^{\mathrm{ab}}$ \\
\hline IT-6h & $11248 \pm 220^{c}$ & $0.65 \pm 0.02$ & $0.64 \pm 0.01$ & $4699 \pm 34.5^{\mathrm{bc}}$ & $0.25 \pm 0.02^{\mathrm{b}}$ \\
\hline IT-8h & $10743 \pm 92.5^{\mathrm{d}}$ & $0.63 \pm 0.04$ & $0.62 \pm 0.01$ & $4185 \pm 125^{\mathrm{d}}$ & $0.26 \pm 0.01^{\mathrm{b}}$ \\
\hline IT-10h & $12708 \pm 357^{\mathrm{a}}$ & $0.62 \pm 0.01$ & $0.64 \pm 0.01$ & $5270 \pm 158^{\mathrm{a}}$ & $0.25 \pm 0.01^{\mathrm{b}}$ \\
\hline \multicolumn{6}{|l|}{ Methods } \\
\hline $\mathrm{CT}$ & $10458 \pm 301^{\mathrm{b}}$ & $0.63 \pm 0.02$ & $0.66 \pm 0.03^{\mathrm{a}}$ & $4301 \pm 572^{\mathrm{b}}$ & $0.27 \pm 0.01^{\mathrm{a}}$ \\
\hline IT & $11641 \pm 799^{a}$ & $0.62 \pm 0.02$ & $0.63 \pm 0.01^{\mathrm{b}}$ & $4665 \pm 428^{\mathrm{a}}$ & $0.25 \pm 0.01^{\mathrm{b}}$ \\
\hline \multicolumn{6}{|l|}{ Time } \\
\hline $4 \mathrm{~h}$ & $11874 \pm 72.2^{\mathrm{a}}$ & $0.63 \pm 0.02^{\mathrm{b}}$ & $0.62 \pm 0.02^{\mathrm{b}}$ & $4613 \pm 184^{\mathrm{a}}$ & $0.26 \pm 0.01$ \\
\hline $6 \mathrm{~h}$ & $11198 \pm 285^{\mathrm{a}}$ & $0.65 \pm 0.01^{\mathrm{a}}$ & $0.66 \pm 0.03^{\mathrm{a}}$ & $4767 \pm 121^{\mathrm{a}}$ & $0.27 \pm 0.02$ \\
\hline $8 \mathrm{~h}$ & $9672 \pm 117^{\mathrm{b}}$ & $0.64 \pm 0.02^{\mathrm{ab}}$ & $0.64 \pm 0.03^{\mathrm{ab}}$ & $3846 \pm 384^{\mathrm{b}}$ & $0.27 \pm 0.02$ \\
\hline $10 \mathrm{~h}$ & $11453 \pm 142^{\mathrm{a}}$ & $0.62 \pm 0.01^{\mathrm{b}}$ & $0.64 \pm 0.01^{\mathrm{ab}}$ & $4707 \pm 248^{\mathrm{a}}$ & $0.26 \pm 0.02$ \\
\hline \multicolumn{6}{|c|}{ Two-way ANOVA } \\
\hline Methods & $<.0001$ & 0.124 & 0.001 & $<.0001$ & 0.001 \\
\hline Time & 0.003 & 0.011 & 0.003 & 0.002 & 0.774 \\
\hline Interaction & $<.0001$ & 0.557 & 0.236 & $<.0001$ & 0.006 \\
\hline
\end{tabular}

Table 3. Effect of different tumbling marination methods and time on the sensory attributes of prepared pork chops.

\begin{tabular}{|c|c|c|c|c|c|}
\hline Items & Tenderness & Color & $\mathrm{O} / \mathrm{F}$ & Juiciness & $\mathrm{O} / \mathrm{A}$ \\
\hline CT-4h & $4.68 \pm 0.38^{d}$ & $5.17 \pm 0.38$ & $4.58 \pm 0.38^{\mathrm{e}}$ & $4.50 \pm 0.25^{d}$ & $4.42 \pm 0.52^{\mathrm{f}}$ \\
\hline CT-6h & $6.08 \pm 0.38^{c}$ & $5.50 \pm 0.25$ & $6.50 \pm 0.25^{c}$ & $6.42 \pm 0.14^{c}$ & $6.92 \pm 0.52^{\mathrm{cd}}$ \\
\hline CT-8h & $8.58 \pm 0.63^{\mathrm{a}}$ & $6.50 \pm 1.09$ & $9.00 \pm 0.50^{\mathrm{a}}$ & $8.75 \pm 0.50^{\mathrm{a}}$ & $8.93 \pm 0.16^{\mathrm{a}}$ \\
\hline CT-10h & $8.08 \pm 0.38^{\mathrm{a}}$ & $5.75 \pm 0.25$ & $7.42 \pm 0.29^{b}$ & $7.42 \pm 0.38^{b}$ & $7.75 \pm 0.25^{b}$ \\
\hline IT-4h & $5.50 \pm 0.25^{c}$ & $5.50 \pm 0.25$ & $5.83 \pm 0.38^{\mathrm{d}}$ & $6.25 \pm 0.25^{c}$ & $5.75 \pm 0.25^{\mathrm{e}}$ \\
\hline IT-6h & $6.25 \pm 0.25^{c}$ & $5.50 \pm 0.25$ & $6.50 \pm 0.25^{c}$ & $6.67 \pm 0.14^{c}$ & $7.08 \pm 0.38^{\mathrm{cd}}$ \\
\hline IT-8h & $7.08 \pm 0.52^{\mathrm{b}}$ & $6.27 \pm 0.28$ & $7.17 \pm 0.29^{b}$ & $6.82 \pm 0.55^{\mathrm{bc}}$ & $7.48 \pm 0.28^{\mathrm{bc}}$ \\
\hline IT-10h & $6.00 \pm 0.25^{c}$ & $5.75 \pm 0.25$ & $6.42 \pm 0.14^{\mathrm{c}}$ & $6.33 \pm 0.38^{c}$ & $6.75 \pm 0.25^{\mathrm{d}}$ \\
\hline \multicolumn{6}{|l|}{ Methods } \\
\hline $\mathrm{CT}$ & $6.72 \pm 1.90^{\mathrm{a}}$ & $5.73 \pm 0.73$ & $6.87 \pm 1.69^{\mathrm{a}}$ & $6.77 \pm 1.65$ & $7.00 \pm 1.76$ \\
\hline IT & $6.22 \pm 0.66^{b}$ & $5.75 \pm 0.39$ & $6.48 \pm 0.55^{\mathrm{b}}$ & $6.52 \pm 0.39$ & $6.77 \pm 0.72$ \\
\hline \multicolumn{6}{|l|}{ Time } \\
\hline $4 \mathrm{~h}$ & $4.79 \pm 0.83^{c}$ & $5.33 \pm 0.34^{\mathrm{b}}$ & $5.21 \pm 0.76^{\mathrm{c}}$ & $5.37 \pm 0.98^{c}$ & $5.08 \pm 0.82^{c}$ \\
\hline $6 \mathrm{~h}$ & $6.18 \pm 0.30^{b}$ & $5.50 \pm 0.22^{b}$ & $6.50 \pm 0.22^{b}$ & $6.54 \pm 0.88^{b}$ & $7.00 \pm 0.42^{b}$ \\
\hline $8 \mathrm{~h}$ & $7.83 \pm 0.97^{a}$ & $6.38 \pm 0.72^{\mathrm{a}}$ & $8.08 \pm 1.07^{\mathrm{a}}$ & $7.78 \pm 1.16^{\mathrm{a}}$ & $8.21 \pm 0.82^{\mathrm{a}}$ \\
\hline $10 \mathrm{~h}$ & $7.04 \pm 1.17^{\mathrm{ab}}$ & $5.75 \pm 0.22^{b}$ & $6.92 \pm 0.58^{b}$ & $6.87 \pm 0.68^{a b}$ & $7.25 \pm 0.59^{b}$ \\
\hline \multicolumn{6}{|c|}{ Two-way ANOVA } \\
\hline Methods & 0.007 & 0.897 & 0.009 & 0.098 & 0.115 \\
\hline Time & $<.0001$ & 0.006 & $<.0001$ & 0.001 & $<.0001$ \\
\hline Interaction & $<.0001$ & 0.769 & $<.0001$ & $<.0001$ & $<.0001$ \\
\hline
\end{tabular}

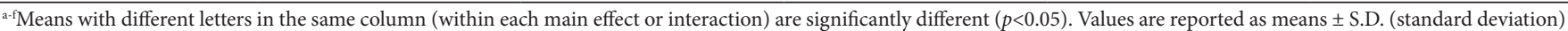
of three replicates. $\mathrm{CT}=$ vacuum continuous tumbling marination; $\mathrm{IT}=$ vacuum intermittent tumbling marination; $\mathrm{O} / \mathrm{F}=\mathrm{overall}$ flavor; $\mathrm{O} / \mathrm{A}=$ overall acceptability. 
tumbling time from $4 \mathrm{~h}$ to $10 \mathrm{~h}$, and the highest results were both obtained at $8 \mathrm{~h}$. Meanwhile, the color, overall flavor and overall acceptability of $8 \mathrm{~h}$ were significantly higher than the other methods $(p<0.05)$. Additionally, there were interactive effects on the sensory attributes (except color) between tumbling methods and tumbling time $(p<0.05)$ with the best results both observed in CT method of $8 \mathrm{~h}$.

\section{Discussion}

The $\mathrm{pH}$ value is one of the most important indicators of meat quality. In this study, the tumbling marination methods significantly increased the $\mathrm{pH}$ of prepared pork chops. The similar observation was also made by Cheng \& Sun (2008), who explained that chloride ions of the marinade solution tended to bind to the meat protein filaments forming an ion"cloud"around them, which aided in the increasing of electrostatic repulsive force within the myofibrils, thus increasing the $\mathrm{pH}$ value. Meanwhile, polyphosphate (alkaline buffer) could increase the electrostatic repulsion and the $\mathrm{pH}$ value by penetrating into the meat (Baublits et al., 2005). Tumbling could also contribute to stimulate the activity of various proteolytic enzymes, which might facilitate the protein degradation and the meat maturity (Lawrie \& Ledward, 2006), and these factors further increased the $\mathrm{pH}$ value of muscle protein. Table 1 showed that the synergistic effect between long tumbling time and CT method was observed for the $\mathrm{pH}$. As the effective tumbling time extending from $4 \mathrm{~h}$ to $10 \mathrm{~h}$, much more marinade solution (mainly $\mathrm{NaCl}$ and polyphosphate) penetrated into the meat causing the increase of $\mathrm{pH}$ value. Moreover, the continuously physico-mechanical action of CT method might be more effective in increasing the $\mathrm{pH}$ compared with IT method.

In the present study, the WHC results were expressed as pressing loss and cooking loss. Based on the results of Table 1, one can conclude that as the effective tumbling time increasing from $4 \mathrm{~h}$ to $8 \mathrm{~h}$, the tumbling and marinade significantly improved the WHC and product yield of pork chops. The present results confirmed the result of Detienne \& Wicker (1999), who explained that the loosening of muscle microstructures and the improving of the $\mathrm{pH}$ as well as the extraction of SSP (including myosin, actin, actomyosin, etc) aided in reducing pressing loss and cooking loss. Additionally, the mechanical tumbling could facilitate marinade effects, and consequently improving the WHC and product yield (Cassidy et al., 1978; Motycka \& Bechtel, 1983). However, as the effective tumbling time increasing up to $10 \mathrm{~h}$, opposite trends of WHC and product yield were observed, which was in accordance with previous observations obtained by Mueller (1989) and Dolata et al. (2004), this was probably due to the severe distortions and excessive destruction of muscle fiber structure. Furthermore, our results also showed that CT method significantly increased the WHC and product yield than IT method, hence the best results were observed in CT method of $8 \mathrm{~h}$.

Both instrumental and sensory tenderness measurements clearly showed that tumbling marination process resulted in a more tender meat (Hullberg et al., 2005; Cheng et al., 2011), which was consistent with the findings in the present study. Results from Table 1 also indicated that, with the effective tumbling time increasing from $4 \mathrm{~h}$ to $8 \mathrm{~h}$, the SFV was closely related to the WHC. After heating, the SSP forms enormous and complicated gel grid microstructures which could maintain amounts of water and fat into the meat and lubricate muscle fibers when chewing them. And tumbling was more important in loosening the muscle structures, destroying the connections between myofibrils and collagen, thus decreasing the SFV and increasing the tenderness (Cassidy et al., 1978; Hayes et al., 2006). Particularly, CT method was more effective in destroying the connection between the myofibers and connective tissue and reducing the SFV (Gao et al., 2014). However, with the effective tumbling time extending from $8 \mathrm{~h}$ to $10 \mathrm{~h}$, the SFV began to increase, which might be related to the decreasing of WHC and the severe destruction of myofiber structure.

Texture and tenderness are presently most important of all the attributes of meat eating quality by consumers (Lawrie $\&$ Ledward, 2006). As the effective tumbling time increasing from $4 \mathrm{~h}$ to $8 \mathrm{~h}$, tumbling marination process significantly decreased hardness and chewiness. And many authors had reported similar results (Pietrasik \& Shand, 2004; Siró et al., 2009), who explained that this was primarily because the changes of the WHC and SFV as they were highly related. Whereas, the improving of springiness and resilience was probably due to the disrupting of the connections between myofibrils and collagen as well as the heated SSP forming elastic gel networks (Pietrasik \& Shand, 2004). It should be emphasized, however, as the effective tumbling time extending from $8 \mathrm{~h}$ to $10 \mathrm{~h}$, opposite trends of TPA results (except cohesiveness) were observed in pork chops. Very similar finding was reported by Siró et al. (2009), who argued that this was probably due to the excessive destruction of the complete framework and structure of muscle fibers during too long tumbling time. Additionally, the TPA results of CT method were better than those of IT method. Briefly, TPA results indicated that CT method of $8 \mathrm{~h}$ was more effective in improving the textural characteristics of prepared pork chops.

It is well known that tenderness and juiciness are essential criterions for eating quality. With the effective tumbling time increasing from $4 \mathrm{~h}$ to $8 \mathrm{~h}$, the disruption of myofibrils and the higher WHC were believed to increase tenderness and juiciness (Sheard \& Tali, 2004). Siró et al. (2009) and Yusop et al. (2012) also demonstrated that, the complicated physico-chemical and biochemical reactions caused by tumbling marination process improved the consistency of meat color distribution and enhanced the formations of aromatic compounds and flavor substances. However, the decreased scores were observed with the tumbling time increasing from $8 \mathrm{~h}$ to $10 \mathrm{~h}$, which was similar to the TPA results. Thus, it can be seen that the $10 \mathrm{~h}$ tumbling time was too long and consequently not suitable for this kind of pork chops. Besides, CT method improved the textural characteristics and sensory attributes of prepared pork chops compared with IT method in spite of tumbling time, which indicated that the continuously physico-mechanical actions of CT method was more beneficial for accelerating marinade efficiency compared with IT method.

\section{Conclusions}

For this prepared boneless pork chops, results showed that regardless of tumbling time, the mechanical effects of CT method was more effective in increasing the $\mathrm{pH}$ value, WHC, tenderness, 
product yield, textural characteristics and sensory attributes. With the effective tumbling time increasing from $4 \mathrm{~h}$ to $10 \mathrm{~h}$, the WHC, tenderness, product yield, textural characteristics and sensory attributes of prepared pork chops increased at first and then decreased. In addition, an interactive effect between CT method and effective tumbling time was observed for the $\mathrm{pH}$ value, product yield, SFV, cooking loss, hardness, chewiness, resilience and sensory attributes (except color). These results demonstrated that CT method of $8 \mathrm{~h}$ obtained the best quality characteristics of prepared pork chops, which should be adopted.

\section{Acknowledgements}

This study was funded by the Ministry of Science and Technology, P.R. China (No. 2012BAD28B03), and the Ministry of Education, P.R. China (No. KYZ201222).

\section{References}

Baublits, R. T., Pohlman, F. W., Brown, A. H. Jr, \& Johnson, Z. B. (2005). Effects of sodium chloride, phosphate type and concentration, and pump rate on beef biceps femoris quality and sensory characteristics. Meat Science, 70(2), 205-214. http://dx.doi.org/10.1016/j. meatsci.2004.12.011. PMid:22063476.

Bourne, M. C. (1978). Texture profile analysis. Food Technology, 32, 62-66.

Cassidy, R., Ockerman, H., Krol, B., Roon, P., Plimpton, R., \& Cahill, V. (1978). Effect of tumbling method, phosphate level and final cook temperature on histological characteristics of tumbled porcine muscle tissue. Journal of Food Science, 43(5), 1514-1518. http:// dx.doi.org/10.1111/j.1365-2621.1978.tb02532.x.

Cheng, J. H., Wang, S. T., Sun, Y. M., \& Ockerman, H. W. (2011). Effect of phosphate, ascorbic acid and $\alpha$-tocopherol injected at one-location with tumbling on quality of roast beef. Meat Science, 87(3), 223-228. http://dx.doi.org/10.1016/j.meatsci.2010.10.013. PMid:21075546.

Cheng, Q., \& Sun, D. W. (2008). Factors affecting the water holding capacity of red meat products: a review of recent research advances. Critical Reviews in Food Science and Nutrition, 48(2), 137-159. http:// dx.doi.org/10.1080/10408390601177647. PMid:18274969.

Detienne, N., \& Wicker, L. (1999). Sodium chloride and tripolyphosphate effects on physical and quality characteristics of injected pork loins. Journal of Food Science, 64(6), 1042-1047. http://dx.doi. org/10.1111/j.1365-2621.1999.tb12278.x.

Dolata, W., Piotrowska, E., Wajdzik, J., \& Tritt-Goc, J. (2004). The use of the MRI technique in the evaluation of water distribution in tumbled porcine muscle. Meat Science, 67(1), 25-31. http://dx.doi. org/10.1016/j.meatsci.2003.09.002. PMid:22061113.

Farouk, M. M., \& Wieliczko, K. J. (2003). Effect of diet and fat content on the functional properties of thawed beef. Meat Science, 64(4), 451-458.

Gao, T., Li, J., Zhang, L., Jiang, Y., Song, L., Ma, R., Gao, F., \& Zhou, G. (2014). Effect of different tumbling marinade treatments on the water status and protein properties of prepared pork chops. Journal of the Science of Food and Agriculture, 95(12), 2494-2500. http:// dx.doi.org/10.1002/jsfa. PMid:25363864.

Gillett, T., Cassidy, R., \& Simon, S. (1982). Ham massaging: effect of massaging cycle, environmental temperature and pump level on yield, bind, and color of intermittently massaged hams. Journal of Food Science, 47(4), 1083-1088. http://dx.doi.org/10.1111/j.1365-2621.1982. tb07624.x.

Hayes, J. E., Desmond, E. M., Troy, D. J., Buckley, D. J., \& Mehra, R. (2006). The effect of enhancement with salt, phosphate and milk proteins on the physical and sensory properties of pork loin. Meat Science, 72(3), 380-386. http://dx.doi.org/10.1016/j.meatsci.2005.05.009. PMid:22061721.

Hayes, J. E., Kenny, T. A., Ward, P., \& Kerry, J. P. (2007). Development of a modified dry curing process for beef. Meat Science, 77(3), 314-323. http://dx.doi.org/10.1016/j.meatsci.2007.03.021. PMid:22061783.

Hullberg, A., \& Lundström, K. (2004). The effects of RN genotype and tumbling on processing yield in cured-smoked pork loins. Meat Science, 67(3), 409-419. http://dx.doi.org/10.1016/j.meatsci.2003.11.015. PMid:22061515.

Hullberg, A., Johansson, L., \& Lundström, K. (2005). Effect of tumbling and RN genotype on sensory perception of cured-smoked pork loin. Meat Science, 69(4), 721-732. http://dx.doi.org/10.1016/j. meatsci.2004.07.013. PMid:22063150.

Kim, S., Choi, J., Choi, Y., Kim, H., Ahn, K., Kim, H., Kim, T., Song, D., \& Kim, C. (2012). Effects of low-temperature tumbling on the quality characteristics of restructured chicken breast ham. Korean Journal for Food Science of Animal Resources, 32(3), 268-273. http:// dx.doi.org/10.5851/kosfa.2012.32.3.268.

Lawrie, R. A., \& Ledward, D. A. (2006). Lawrie's meat science (7th ed.). Cambridge: Woodhead Publishing.

Motycka, R. R., \& Bechtel, P. J. (1983). Influence of pre-rigor processing, mechanical tenderization, tumbling method and processing time on the quality and yield of ham. Journal of Food Science, 48(5), 1532-1536. http://dx.doi.org/10.1111/j.1365-2621.1983.tb03531.x.

Mueller, W. D. (1989). Technology for cooked cured products. Fleischwirtschaft, 69(9), 1425-1428.

Ockerman, H., \& Organisciak, C. (1978). Diffusion of curing brine in tumbled and non-tumbled porcine tissue. Journal of Food Protection, 41(3), 178-181.

Peña, F., Avilés, C., Domenech, V., González, A., Martínez, A., \& Molina, A. (2014). Effects of stress by unfamiliar sounds on carcass and meat traits in bulls from three continental beef cattle breeds at different ageing times. Meat Science, 98(4), 718-725. http://dx.doi. org/10.1016/j.meatsci.2014.07.021. PMid:25105491.

Pietrasik, Z., \& Shand, P. J. (2004). Effect of blade tenderization and tumbling time on the processing characteristics and tenderness of injected cooked roast beef. Meat Science, 66(4), 871-879. http:// dx.doi.org/10.1016/j.meatsci.2003.08.009. PMid:22061020.

Plimpton, R. F., Perkins, C. J., Sefton, T. L., Cahill, V. R., \& Ockerman, H. W. (1991). Rigor condition, tumbling and salt level influence on physical, chemical and quality characteristics of cured, boneless hams. Journal of Food Science, 56(6), 1514-1518. http://dx.doi. org/10.1111/j.1365-2621.1991.tb08629.x.

Ruiz de Huidobro, F., Miguel, E., Onega, E., \& Blázquez, B. (2003). Changes in meat quality characteristics of bovine meat during the first 6 days post mortem. Meat Science, 65(4), 1439-1446. http:// dx.doi.org/10.1016/S0309-1740(03)00068-8. PMid:22063789.

Saha, A., Lee, Y., Meullenet, J. F., \& Owens, C. M. (2009). Consumer acceptance of broiler breast fillets marinated with varying levels of salt. Poultry Science, 88(2), 415-423. http://dx.doi.org/10.3382/ ps.2008-00230. PMid:19151357.

Sheard, P. R., \& Tali, A. (2004). Injection of salt, tripolyphosphate and bicarbonate marinade solutions to improve the yield and tenderness of cooked pork loin. Meat Science, 68(2), 305-311. http://dx.doi. org/10.1016/j.meatsci.2004.03.012. PMid:22062241.

Siró, I., Ven, C., Balla, C., Jónás, G., Zeke, I., \& Friedrich, L. (2009). Application of an ultrasonic assisted curing technique for improving the diffusion of sodium chloride in porcine meat. Journal of Food Engineering, 91(2), 353-362. http://dx.doi.org/10.1016/j. jfoodeng.2008.09.015. 
Straadt, I. K., Rasmussen, M., Andersen, H. J., \& Bertram, H. C. (2007). Aging-induced changes in microstructure and water distribution in fresh and cooked pork in relation to water-holding capacity and cooking loss - A combined confocal laser scanning microscopy (CLSM) and low-field nuclear magnetic resonance relaxation study. Meat Science, 75(4), 687-695. http://dx.doi.org/10.1016/j. meatsci.2006.09.019. PMid:22064034.

United States Department of Agriculture - USDA (2013). Natural Resources Conservation Service. Washington. Retrieved from http://www.nrcs. usda.gov/wps/portal/nrcs/detail/national/technical/?cid=nrcs143_014.
Yusop, S. M., O’Sullivan, M. G., Kerry, J. F., \& Kerry, J. P. (2010). Effect of marinating time and low $\mathrm{pH}$ on marinade performance and sensory acceptability of poultry meat. Meat Science, 85(4), 657-663. http://dx.doi.org/10.1016/j.meatsci.2010.03.020. PMid:20416811.

Yusop, S. M., O’Sullivan, M. G., Kerry, J. F., \& Kerry, J. P. (2012). Influence of processing method and holding time on the physical and sensory qualities of cooked marinated chicken breast fillets. Food Science and Technology, 46(1), 363-370. http://dx.doi.org/10.1016/j. lwt.2011.08.007. 